\title{
Wikileaks and consequences for modern diplomacy - observations by a foreign policy practitioner
}

\author{
Jørgen Ørstrøm Møller Ambassador (rd.) \& State-Secretary (rd.), Ministry of Foreign Affairs of \\ Denmark; Visiting Senior Research Fellow, Institute of Southeast Asian Studies, Singapore; Adjunct \\ Professor at Singapore Management University \& Copenhagen Business School; Senior Fellow, \\ Diplomatic Academy, Singapore.
}

Wikileaks did not reveal much, we did not know about U.S. foreign policy already. The true revelations were - as many had suspected - that some foreign leaders pursue a different foreign policy agenda than the official one. Sources providing information to foreign diplomats will be more prudent from now on. The main impact is a new type of diplomacy bypassing leaders to communicate directly with the people - increasing people's power and highlighting the growing importance of civic society and the social media.

\section{Wikileaks and raison d'état}

At the Peace Conference in 1918 after World War I, U.S. President Woodrow Wilson, often seen as the founding father of the idealist streak in American diplomacy, stated his fourteen points to secure a lasting world peace. He set out by stating the following:

"We entered this war because violations of right had occurred which touched us to the quick and made the life of our own people impossible unless they were corrected and the world secure once for all against their recurrence. What we demand in this war, therefore, is nothing peculiar to ourselves. It is that the world be made fit and safe to live in; and particularly that it be made safe for every peace-loving nation which, like our own, wishes to live its own life, determine its own institutions, be assured of justice and fair dealing by the other peoples of the world as against force and selfish aggression. All the peoples of the world are in effect partners in this interest, and for our own part we see very clearly that unless justice be done to others it will not be done to us. The program of the world's peace, therefore, is our program; and that program, the only possible program, as we see it, is this."

Wilson then continues to present his fourteen points of which the banishment of 'secret diplomacy' is the most well known and undeniably the most important to his own mind. This can be concluded from the simple observation that it was the first one on his list:

"Open covenants of peace, openly arrived at, after which there shall be no private international understandings of any kind but diplomacy shall proceed always frankly and in the public view."'

The underlying principle here is the conviction that World War I was caused by secret undertakings and covert agreements among the Great Powers of Europe, guaranteeing to support each other in case of war. So when Russia felt it was necessary to counteract the AustrianHungarian aggression against Serbia, Germany had to support Austria-Hungary, which in turn forced France to become involved as well. Such a network of alliances made negotiations impossible and dragged peoples into war without giving them any opportunity to voice their opinion. 
What is often overlooked, however, is that Great Britain - the most crucial Great Power - went to war to support France, not as a result of any treaties or secret undertaking, but rather because of informal consultations and coordination on a lower level - albeit tying the hands of the government in no less stringent a manner. It underlines, however, that despite all kind of commitments, it is extremely difficult - if not impossible - to box nation-states and their diplomacy into a strait jacket of rules that may force them to act against their interests.

As the French Foreign Minister retorted in those first days of August 1914 when asked by the German Ambassador, how France would act if Germany went to war with Russia, he replied: "La France agira selon ses interest". Diplomacy is an instrument for nation-states to pursue their interests. No treaty, no agreement, no undertaking, nor anything else that can be put on the table will compel a nation-state to act against its interests. Formalities cannot bend realities.

When trying to distil the effects of Wikileaks for future diplomacy, raison d'état stands out as the first observation, but ultimately also the conclusion. The awareness that information may be made public - despite the government's wishes - may change the working methods and instruments chosen by diplomacy, but not its raison d'etre - to pursue and safeguard interests.

In the following we will first discuss secret diplomacy versus non-secret (open) diplomacy. Then the essay will examine what we learned from Wikileaks and how Information and Communication Technology (ICT) changes diplomacy. Finally the essay will conclude with expectations for the future of modern diplomacy.

\section{Secret versus non-secret diplomacy}

It should not be overlooked that there are indeed good reasons for secret diplomacy, even if abuses unveiled by history has discredited such undertakings.

One explanation - not necessarily a good one, but nonetheless one often used - is that foreign policy is a topic best dealt with outside the normal sphere of domestic policy processes. The reasoning goes that the majority of parliamentarians and especially the majority of voters do not have sufficient foreign policy insight to adopt a sensible attitude towards complex foreign policy issues. In Denmark this reasoning is institutionalized in the foreign policy committee, which is anchored in the Danish Constitution, $\$ 19.3$. This is the only example of a Parliamentary Committee being mentioned in the Constitution - clearly an indication that foreign policy is 'special'.

There may, however, be some truth to this view, primarily because diplomats are supposed to - and fortunately in most cases do - know more about the circum- stances and dispositions of foreign nation-states. The fact, which is difficult to overlook, is that people who have lived their entire life inside a nation-state are likely to expect other nation-states to act analogously, while people having lived outside the borders (i.e. diplomats) know that this is not necessarily the case.

A good illustration of this can be found in the U.S. policy towards the People's Republic of China in the beginning of the 1970's when President Nixon and his National Security Adviser Henry Kissinger fundamentally revised U.S. policy towards China through secret negotiations. Nixon and Kissinger would probably never have been able to perform this diplomatic act, had they been forced into an open debate. The perception of China among the large majority of Americans and indeed the majority of members of the U.S. Congress would have blocked such an initiative. Admittedly this perception was fuelled by decades of American propaganda depicting China as an evil communist power. Nixon and Kissinger knew, however, that to counteract the Soviet Union and force it into agreements on weapons control, China was an indispensable card to be played in the dawning Triangular Diplomacy.

In Denmark we have also had our share of secret diplomacy. In 1957 there was secret acknowledgement by senior officials in the Danish government of 'ammunition of a distinctive character' to be stored by the U.S. military in Greenland, despite the fact that Denmark's official policy was to reject nuclear weapons on Danish territory during peacetime. Apparently only two people knew about this - the Foreign Minister (who was also Prime Minister at that time) and his Permanent Secretary. They undoubtedly acted out of the belief that this was in the national interest, and that it was not a policy the public would endorse. It therefore had to be kept a secret.

To my mind - partly coloured by personal experience in the Danish Diplomatic Service - there are two motivations for secret diplomacy that stand even if scrutinized by a high moral standard. ${ }^{3}$

The first one is that in the age of multilateral diplomacy, the game has become much more complicated. Countries negotiate not with one other country, but with many other countries simultaneously. And the result is not confined to one single issue, but covers a large number of issues as is seen e.g. in the European Union (EU), in the World Trade Organization (WTO), and in the United Nations (UN) and in many other international or multilateral organizations.

This demands the ability to weigh a concession now, given to one state in one issue-area, against potential future concessions offered in another area by other nation- 
states. A result may be seen as negative here and now with one nation-state seen as the loser, but concessions in the pipeline from other nation-states may alter the equation and ultimately produce a win-win situation for nation states.

The crucial point is that if the country offering a concession now cannot be sure of getting something in return at a later stage and in another context, it will not make the offer of a concession in the first place. In other words: Leaks of secret diplomatic deals may force partners in the negotiation to abandon pledges given in good faith during earlier negotiations, jeopardizing much of the structure of multilateral diplomacy. Multilateral diplomacy rests on the assumption that in a longer run and seen as a whole, all countries benefit from international cooperation - but benefits and burdens from a specific negotiation do not necessarily accrue to the same groups inside a given nation-state e.g. a country may gain during the negotiations of agricultural prices in the EU and then at a later stage be asked to 'pay' when fisheries quotas are negotiated. The negotiators may see the deal as beneficial to the nation-state as a whole, but the fishermen may not. Given the opportunity presented by leaks of such diplomatic understandings, special domestic interest groups may try to prevent the concession in the pipeline.

The second motivation is strategic ambiguity. Most observers would agree that strategic ambiguity has served the world very well inter alia in the triangle China-Taiwanthe U.S.

To prevent other nation-states from taking certain steps, a sensible policy may be to keep them guessing what would happen, if they actually did take these steps. But such a policy cannot be enacted if open diplomacy forces full disclosure about the foreign policy dispositions of countries in any eventuality. The guessing game is an important part of diplomacy and in most cases it works as a barrier to conflicts. The majority of nation-states adopt a prudent posture when they do not know what will happen if they do something other nation-states have signalled will be met with opposition. My professional experience is that the overwhelming majority of governments are risk aversive in foreign policy.

In a way we can say that open diplomacy in certain circumstances can tie the hands of governments in exactly the same way as secret diplomacy did before World War I. If nation-states and their governments publicly have committed themselves, the situation is not much different. They have to act according to their statements and resolutions adopted in parliaments and pledges during electoral campaigns.
In sum room of manoeuvre combined with wilful ambiguity are some of diplomacy's finest instruments - and it is hard to reconcile such instruments with openness.

\section{What did Wikileaks tell us?}

The amount of diplomatic cables made public is enormous to be frank: 251,287 according to a figure mentioned in September 2011. ${ }^{4}$ And yet the multitude of cables tell us very little we did not know or suspected about U.S. foreign policy already. In my opinion the following conclusions can be drawn from the Wikileaks.

The first one is that U.S. diplomacy is a gigantic machine, reaching far beyond classic diplomacy concentrated on foreign- and security policy items. U.S. diplomats looked for evidence of a wide range of policies of nation-states, covering even societal policies e.g. What does the country intend to do, what is its social fabric and how can it be expected to act in the future.

Recently, collection of what is called 'big data' - or 'mega data' - has attracted attention as an instrument for predicting future trends (Weinberger 2011, 32-37). The basic idea behind the 'big data' idea is to simulate not specific topics but everything all at once thus getting answers or probabilities out of the data input. The U.S. diplomatic machine does not collect 'big data' as such, but bears a certain resemblance in its seemingly unwritten drive to collect data from all sources and areas in order to shape a coherent picture of what other countries intend to do. Reviewing the magnitude of data published by Wikileaks, it is amazing what we have here.

The missing point - which the theory about 'big data' tries to plug - is how to put all these pieces of data together - a model or theory so to speak. Comparing the diplomatic cables released by Wikileaks with the actual U.S. diplomacy, it is evident that this is exactly where the U.S. failed. All the information is evidently there, but the method to combine the data to form a holistic picture is absent. It is a kind of fast stream river rushing downstream without any kind of control.

There is one more conclusion to draw from the discussion about 'big data', which is the changing perception of knowledge or the shift of borderlines between objectivity and subjectivity (Møller 2011: 12). ${ }^{5}$ Over the last couple of centuries we have grown used to see knowledge as something objective - something that could be verified. We relied on scientific methods refined over many decades to get to the truth, which subsequently was labelled knowledge. But Wikileaks shows how 'big data' transforms knowledge from objectivity to subjectivity. The large stream of data being cabled in from capitals around the world is clearly not undisputed truths. In fact 
it gives rise to many arguments pro et contra, with different sources in the cables taking different views Gradually, almost without really noticing, we see that data is something we can influence.

Science itself has since the Heisenberg uncertainty principle in quantum mechanics from 1925 moved away from pure objectivity towards as the words indicate uncertainty and more inaccuracy. In scientific terms this is obviously a watershed, but it may be even more important in implanting the fundamental philosophy that things are not so certain and accurate as science over several hundred of years had taught. In 1958 Norwood Russell Hanson put forward his theory that what we see is not objective, but that the result of observing something depends to a certain degree on the observer; what our senses receive is actually filtered sensory information.

Most non-scientists have not really bothered about this change of direction in science, but with the datastream, it becomes something relevant for the future direction of our societies.

The second conclusion is the confirmation of how much the U.S. relies on computerized input. Indeed one of the explanations for Wikileaks is that the data were there, available, having been collected by the US foreign policy machine.

Old-fashioned diplomacy was much more dependent on human contacts supplying qualified information. The people who collected the information had used most of their lives to build up an understanding of the background and implications of the events they observed. Wikileaks reveals a trend towards raw quantitative data - information yes, but to a large degree unqualified and non-evaluated information.

What strikes a diplomat when reading through the Wikileaks cables is the raw nature of data coming into the U.S. State Department. There is nothing per se wrong with raw data, provided that somewhere in the pipeline some kind of examination or systematization of the data takes place. With Wikileaks this seems not to have been the case. As has been illustrated by subsequent analysis of the information available prior to the terrorist attacks on September 11, 2001, all the information predicting the attack was there, but the ability to put the pieces together was not ${ }^{6}$.

For a diplomat with 38 years of foreign policy experience, it seems evident that information is useless, if a machinery to analyse it to form a broader picture has not been established. What is the use of knowing the thinking of a large number of people, if that does not lead us to know or be able to predict what the country's policies are going to be?
There has been much talk about a coming new age of diplomacy after Wikileaks, where anybody may potentially get access to anything. An equally important conclusion to draw - and question - is how much personal diplomacy, personal relations, and qualified, individual judgment has been pushed into the background.

The third conclusion is - for many somewhat surprising but in a way rather ironic - the U.S. actually means what it says! Even close scrutiny of the vast amount of documents does not really point to discrepancies between public statements and official policy on the one hand and what U.S. diplomats around the world actually do on the other hand. There is a high degree of congruity, which creates credibility about U.S. diplomacy. Many observers and critics of the U.S. will certainly be disappointed about such a disclosure. Some of them may retort that the discrepancy, which they want to see, is found if we knew equally well what the CIA or similar agencies were doing. Very little harm - if any harm at all - is being done to U.S. foreign policy room of manoeuvre at home.

The fourth conclusion may also come as a surprise at least for those acquainted with old-fashioned diplomacy. Much of the data is about what the U.S. is saying to other nation-states and how American diplomats are trying to persuade other nation-states what their policies should be. Genuine and old-fashioned diplomacy was primarily about finding out the intentions of what the host country intends. The golden rule was not to interfere in the domestic politics of other nation-states - if not for other reasons, then because interference would potentially reduce the amount of incoming information. Usually, people do not want to be told by foreign diplomats what their country should do or mean.

This is, however, how diplomacy carried out by large and more powerful nation-states has developed over the recent decades. My own personal experience bears witness to this. Ambassadors from larger countries often came to see me - not to hear about the Danish position, but rather to tell me what it should be or explain why Denmark should try to convince some other countries that their positions were wrong. I recall an ambassador coming to see me about an American initiative for USEU cooperation. We agreed that it was not clear what the US actually wanted, and subsequently he went on to say "as it is not clear what they mean, why don't we explain to them what they mean".

The U.S. as a global superpower is pursuing certain goals in its diplomacy through diplomats stationed in foreign countries. Wikileaks discloses how this big machine is used not only to safeguard American interests, 
but also to try to alter the policies of other nation-states in a direction conducive to American interests. There are serious doubts about the soundness of such an approach in the long run. American diplomacy has been extremely effective in what could be termed grand strategy i.e. overarching policies vis-à-vis the Soviet Union or vis-a-vis China. But the subtlety of US foreign policy when dealing with medium sized powers and small nation-states has never won much praise. When you carry a big stick, it is apparently difficult not to let the person on the other side of table know that this is indeed the case.

The fifth conclusion is that a large number of political leaders in other countries have adopted a different - sometimes the completely opposite - attitude than the country's well-known and publicly stated policy, when dealing with the U.S.

Wikileaks reveals that most - if not all - of the countries in the Middle East favour action against Iran to prevent it from developing nuclear weapons. This does not come as a surprise to people following foreign- and security policy. We know it as the raison d'être of nationstates. Politics is dictated by national interests and the countries of the Middle East know that a nuclear Iran will destabilise the balance of power in the region - with ramifications far beyond Israel (The fear of a nuclear Iran may be more manifest in some of Iran's immediate neighbours).

But over the years Iran has played its hand cunningly, by publicly stating again and again that development of an Iranian nuclear bomb should be seen in the context of hostility towards Israel, making it difficult, if not to say impossible, for leaders in Arab countries to speak out against it.

Wikileaks brought into the open, that Arab leaders in private conversations - notwithstanding that no such thing as private conversation exists between a political leader and an emissary from a foreign power ${ }^{7}-$ strongly opposed Iranian nuclear weapons and even encouraged the U.S. to take action. The private exhortations by Saudi Arabia's King Abdullah for Washington to "cut off the head of the [Iranian] snake" 8 may again not be revelation for Western observers, but it may be for a large number of Arabs, having lived in the belief that Saudi-Arabia supported policies aimed against Israel. King Abdullah may thus face a problem vis-à-vis many of his own citizens and many citizens in other Arab countries, not only for stating this policy goal, but also for his choice of vocabulary. In the same way expressions detailing critical comments of Pakistan's political leaders by the King of Saudi-Arabia and Abu Dhabi Crown Prince Muhammad Bin Zayed will likewise give rise to lifted eyebrows in the Arab and/ or Muslim world.

\section{The future of diplomacy}

Much of the debate in the aftermath of Wikileaks has focused on whether sources will be as ready to talk as hitherto and whether they will weigh their words more carefully - even cautiously - in the future.

The immediate observation is that interaction between a diplomat and a source is not one sided, but a quid pro quo. Sources willingly enter into conversation with diplomats either because it is their job to communicate with foreign diplomats or because the source may want to feed some input into the decision making process of the foreign country in question. The answer to the first question is therefore that there will not be much difference in the availability of sources in the future.

There may, however, be a difference when pondering about how open sources will be compared to the past and whether sources will use the same kind of vocabulary. This is a sensitive area. In my opinion sources - and I have often been a source for foreign diplomats working in Denmark - try to tune into their interlocutor for various reasons. It makes the conversation easier; it improves the chances of getting messages through; and it creates goodwill, which may come in handy at other occasions. Therefore not all they say can be taken at face value. A seasoned diplomat understands this and distils the information from the source, before submitting it back to capitals. I do not remember one single time in my capacity as an Ambassador to have transmitted ad verbatim as Wikileaks reveals has been the case on many occasions. When working at headquarters and receiving cables from Danish diplomats, I never took such wording at face value, but always tried to digest what the source really meant, trying to understand the deeper message.

Wikileaks disclose that many American diplomats did not understand this, conveying information from sources back to back to headquarters without reservation. This was a grave mistake. One does not need diplomats for doing that. No experienced and able diplomat would have conveyed expressions and exhortations as found on Wikileaks to headquarters. They should have known that this vocabulary was used in the context of a conversation and, although expressing a policy stance, did not reflect the full position of the host country. Headquarter has no need for specific phrases unless circumstances are special, headquarters need input and judgment. Colourful language sounds good when spoken, but may lead to toe curling when put on paper.

Now when we know that American diplomacy and probably also the diplomatic services of many other coun- 
tries have forgotten this or put that priceless dictum on the backburner, vocabulary may change, becoming flat, more obscure, more opaque and more ambiguous. Ambiguity is sometimes - maybe more often than not - a good thing in a policy stance, but it is extremely dangerous when collecting information and data to form a picture of foreign powers intentions. There is a place for ambiguity in policy stance, but not in the analytical phase.

History has many examples of how this kind of ambiguity has dangerous consequences. Two of them may have contributed to outbreak of war.

The first example took place in the aftermath of World War II and may have contributed to outbreak of the Korean War. In February 1950 Secretary of State Dean Acheson gave a speech at the Press Club in Washington D.C. and mentioned the American defence perimeter in Asia, pointing to a map indicating that it ran between Japan and Korea. In other words Acheson seemed to indicate that Korea was outside, rather than inside, the American defence perimeter. In June 1950 North Korea unleashed its army against South Korea. We do not know exactly what reasoning was behind the attack and what if any - role Dean Acheson's speech may have played, but it is normally assumed that this speech was at least one of several indications that lead North Korea to believe that the U.S. might not defend South Korea (Matray 2002).

Another example is the still on-going debate about the meeting between Iraqi President Saddam Hussein and the American Ambassador April Glaspie in 1990, prior to Iraq's invasion of Kuwait. There is no clear conclusion whether her statements did or did not confirm Saddam Hussein in his belief that the U.S. would not step in to defend Kuwait. For this purpose it is sufficient to note that the American Ambassador when summoned without warning to the meeting did not make it abundantly clear that this would be the case. This is no criticism of her behaviour; there is no evidence to do that, but a statement of fact.

These two events point to the risk of unclear messaging. Wikileaks will push conversations between diplomats and their sources in the direction of boring and sometimes obscure vocabulary, making it harder for diplomats to get the sense of what the host country intends to do. A seasoned diplomat, a good diplomat, will not depend on the exact wording and will probe until he/ she knows for sure what they have come to find out. But as history shows not all diplomats fall in this category, unfortunately. In short: Wikileaks enhances the risk of incomplete information gathering, because sources will be more cautious and ambiguous when talking to diplomats, thus making it more difficult for diplomats to get a final sense of what the host country intends to do.
A second risk stemming from Wikileaks is that sensitive information gathering takes place outside normal diplomatic circles, using non-diplomatic channels. Sensitive information may even be transmitted verbally to avoid archives and risks of subsequent leaks.

Obviously this increases the risk of misunderstandings and ambiguity. Sources outside normal diplomatic channels are associated with greater risk in the sense that they may not be used to talk with diplomats. They may not have the same access to government policies as 'serious' sources, but unwilling to admit so. The quality of sources diminishes. It may also be unclear what they actually said if transmitting procedures outside established channels are used inter alia if it is done verbally through special emissaries.

As the Cuban missile crisis as well as Henry Kissinger's preliminary talks when establishing contact with China showed, channels outside diplomacy have been used successfully, but again this primarily took place in exceptional circumstances.

The real impact on diplomacy of Wikileaks is, however, to be found in an analysis of how Information and Communication Technology (ICT) i.e. facebook, twitter and other social media changes diplomacy. The U.S. government has set up a centre that follows up to 5 million tweets a day. The centre also pores over "Facebook, newspapers, TV news channels, local radio stations, and Internet chat rooms - anything overseas that anyone can access and contribute to openly".

There are three major and fundamental changes in the pipeline. The first one is the ability of a given country to conduct a swift analysis of the public reaction in foreign countries of this particular country's own foreign- and security policy initiatives. The U.S. for example does that after major Presidential speeches or other policy steps (e.g. the killing of Osama bin Laden) to gauge the reaction of - not official sources or governments - but the public. This gives an immediate picture of the public sentiment. As phrased in the source referred to in the previous paragraph:

"From Arabic to Mandarin Chinese, from an angry tweet to a thoughtful blog, the analysts gather the information, often in native tongue. They crossreference it with the local newspaper or a clandestinely intercepted phone conversation. From there, they build a picture sought by the highest levels at the White House, giving a real-time peek, for example, at the mood of a region after the Navy SEAL raid that killed Osama bin Laden or perhaps a prediction of which Mideast nation seems ripe for revolt". 
The second change is the deeper understanding of what moves outside official circles in a country and which trends are emerging with the necessary public support to ultimately engineer changes. Most diplomats recall how unexpected the uprising in Iran in 1979 against the Shah was. Many people would think that the uprising in Egypt against President Mubarak also came as a surprise - albeit not in the same league. But for the CIA-unit monitoring facebook, twitter etc. it did not. The centre knew of the discontent brewing in the Egyptian population and something like this would eventually come, even though the centre could not foresee exactly how and when. But it was enough to warn the U.S. government and may have been instrumental in the U.S. policy response, informing the U.S. government that the uprising enjoyed broad popular support and consequently that President $\mathrm{Mu}$ barak could not be kept in power irrespective of whether American interest pointed in that direction or not.

Compared to such analysis of ICT (with resemblances to 'big data') traditional diplomacy falls short. Indeed traditional diplomacy may get it wrong, because it draws predominantly on established sources. It is wellknown that the U.S. for many years relied - at least partly - on intelligence services in a number of Middle East countries (including Egypt), not so much to know about other countries, but to know about the country in question. The danger or risk is that if domestic intelligence services get it wrong, as they did in Iran prior to 1979 and may have done in Egypt when the Arab Spring erupted, the U.S. also gets it wrong. Intelligence services are not vaccinated against human errors and shortcomings in the sense that they are lured into seeing and thinking what they expect to see. They are also bureaucracies driving in the familiar side of the road and have evidently not in several cases been able to understand the implications of ICT for building popular support for or against the incumbent regime.

The third change may be the most intriguing one. It is the ability to manage foreign- and security policy over the heads of other governments, building coalitions or understandings with the people in other countries.

To a certain extent this was what President Obama tried to do with his speeches in Istanbul (April 2009) when he addressed the Middle East problems and a cou- ple of months later when he addressed the Muslim world with a major speech in Cairo (June 2009). The aim may have been less to communicate with the political leaders in the region whom he knew quite well, but rather to reach out to the peoples in the region, trying to rally them behind alternative policies than the established line of thinking in these countries.

Technically, it may be possible to block or at least make such behaviour difficult and reduce its impact, but in the long run it is a lost battle as the message can and will be conveyed through ICT to the population. We do not know whether President Obama's two speeches played a role in what happened two years later in the Arab Spring, but it is possible that it fitted into one of many converging trends, pushing the populations of the Arab countries towards protests demanding regime changes.

Traditional diplomacy finds it difficult - maybe even impossible - to compete with this new and strong instrument for reaching out. A diplomat is constrained by a number of rules, which cannot be neglected. The host country expects diplomats to play by these rules and if they do not, they may be denied access to sources and in the worst cases be asked to leave the country as a persona non grata. No such inhibitions exist for using ICT to go beyond the governments and appeal directly to the people.

\section{Conclusion}

The following conclusions can be drawn from Wikileaks:

- Wikileaks had little impact on the U.S. itself as congruity between official policy and diplomacy abroad was demonstrated.

- Wikileaks had some impact on foreign countries, especially in the Middle East, where political leaders were caught supporting U.S. policies, which they had publicly denounced.

- More prudence and more ambiguous use of vocabulary in the future among sources, boding a deterioration of the quality of information gathered by diplomats abroad.

- A huge swing away from traditional diplomacy to the increasing use of ICT as both an instrument in intelligence gathering, but also as a new method of reaching out to the populations bypassing recalcitrant governments. 


\section{Litteratur}

Hanson, NR. 1958, Patterns of Discovery: An Inquiry into the Conceptual Foundations of Science. Cambridge University Press, 1958

Matray, JI. 2002: 'Dean Acheson's Press Club Speech Reexamined', Journal of Conflict Studies, 22 (1)

Møller, JØ. 2011, How Asia Can Shape the World - From the Era of Plenty to the era of Scarcities 2011, ISEAS.

Weinberger, D 2011, 'The Machine That Would Predict the Future', Scientific American Magazine.

\section{Notes}

1. Wilson, Woodrow (8 January 1918). President Wilson's Fourteen Points. Retrieved on 12 March 2012 at http://wwi.lib.byu.edu/index.php/President_Wilson\%27s_Fourteen_Points

2. France will act in accordance with its interests.

3. Others may also stand scrutiny in a logical and/or intellectual analysis, if we accept the premise that those in power know best. But as history has shown this is not always the case.

4. BBC (2 September 2011). Anger as Wikileaks releases all US cables. Retrieved on 12 March 2012 at http://www.bbc.co.uk/news/worldus-canada- 14765837
5. Objectivity versus subjectivity is discussed in my book How Asia Can Shape the World - From the Era of Plenty to the era of Scarcities.

6. The same was the case prior to the attack on Pearl Harbor 7 December 1941.

7. During the Cuban Missile Crisis the U.S. at the eleventh hour offered the Soviet Union what Attorney General Robert Kennedy and Ambassador Dobrynin understood as a 'private' deal about U.S. missiles in Turkey. The words "private' covered that it was never to be made public and if mentioned publicly would be denied by the U.S. This case offers an example of the virtues of secret diplomacy under special circumstances.

8. Council on Foreign Relations (1 December 2010): Will WikiLeaks Hobble U.S. Diplomacy?. Retrieved on 12 March 2012 at http:// www.cfr.org/diplomacy/wikileaks-hobble-us-diplomacy/p23526

9. Associated Press (6 november 2011). CIA following Twitter, Facebook. Retrieved on 12 March 2012 at http://sg.news.yahoo.com/ ap-exclusive-cia-following-twitter-facebook-081055316.html 